\title{
Madukaku as the Basis of Being Human in (Igbo) African Worldview; A Critical Reflection
}

\author{
Bassey Samuel Akpan, Okpe, Timothy Adie \\ Department of Philosophy, University of Calabar, Calabar, Cross River, 540242, Nigeria \\ samuelbassey15@yahoo.com
}

\begin{abstract}
Critical understanding of Western idea of human personality reveals a lot of weaknesses. It reveals individualistic and anthropocentric tendency which is the reason for unpleasant relationship between man and fellow man and man and the environment. This kind of thinking has led Western environmental ethicist to now propound theories towards communitarian stand, for instance; deep ecology, land ethic, eco-feminism to mention a few. Enyimba, Maduka holds a radical point of view from many African communal philosophers. Maduka holds that a person is human because he/she is worth more in quality and essence than other beings and things. Such thinking has been the underlying rationale behind man's overexploitation of nature. The thrust of the essay is to look at the basic tenets of Madukakism as the philosophy of being human in Africa. This paper agrees with the idea of Madukaku that humanity is at the centre of the universe, but differs from its individualist assumptions. In African ontology, the hierarchy of beings, God, lesser deities and ancestors are above human, If this is the case then man is not supreme and cannot be 'the measure of all things'. Hence this paper rejects Maduka's postulation of human being as supreme, because even within African environment there are some trees, rivers, mountains etc that are considered sacred and its therefore considered a taboo to toy with them. To this, no matter how highly placed man is, he is not allowed to touch nor exploit them, without dare consequence, which clearly shows that man is not the measure of all things but is in a complimentary state with other beings in African belief system.
\end{abstract}

Keywords : Madukakism; ontology; communitarianism; beings

\section{Introduction}

From ancient times till date, man has continued on an endless pursuit to discover and provide answers to essential questions that bother around the nature of the world, the nature of his existence as a person and the nature of his existence as a living being in the world (Wogu, 67) Philosophy centers on the investigation of the human condition. Human often tries to seek and explain his existence and tries to assigns importance to the world he finds himself in and life itself. According to popular belief, existence cannot be "thought away," and thus existence (being in the world) precede consciousness, and as such it seems the ultimate reality. Based on this, Sartre is known for a core premise: "Existence precedes essence" (Atwell, 580). He is of the opinion that because humans define their own essence, (which means that they choose their purposes and interpret the world in which they find themselves) they must exist prior to doing so. This view means that self, psyche, and personhood evolve from one's being. Or, as Sartre opine: "Man is nothing else than what he makes of himself, such is the first principle of Existentialism" (Çelebi, 32). Enyimba, Maduka presents the idea of Madukaku, which is similar to the thinking above. The concept 'Madukaku' is that a person in African culture is human because he/she is worth more in quality and essence than other beings. This philosophy is said to be based on an African (Igbo) worldview, but rejects earlier African communitarian postulations. The aim of this paper is to critically review the philosophy of Madukaku as been exposed by Enyimba, Maduka. This paper submits that such postulations have an anthropocentric undertone, which 
is alien to African system of thought. Centered to this, this paper questions what Madukaku means when saying human possesses distinguishing features which place them over and above 'other beings'. Does this 'other beings' include God, lesser deities and the ancestor's? Does 'other beings' only mean things within the physical environment? If man is the measure of all things in African thought, how does he explain the taboo and totem in African culture which is supposed to be beyond human reach? This paper submits that the concept of Madukaku is alien to African system of thought using African communal thought and African ontology to explain its postulations.

\section{Review of Literature}

\subsection{Madukaku; A Conceptual Clarification}

According to Enyimba, Maduka, the concept of Madukaku is said to be co-jointed with two Igbo words. Which are-Madu,-aku and-Ka respectively (225). Its English equivalent according is;-'human',-'wealth' and-'is greater than'. According to the author he claimed that 'Wealth here can refer to anything else outside the human person' (225). More specifically he claimed that, 'In fact, non-human entities or objects constitutes what is called wealth' (225). To this, I understand the word 'wealth' here to mean 'being', anything that exist, be it metaphysical and physical. It is important to know that the word 'wealth' in Igbo reality also include human, as some few names in the Igbo culture reveals this; for instance Akuabata, which implies that Wealth has come in, and also Akunna and also means Father's wealth. To drive home his postulations Enyimba Maduka posits that

'For the Igbo speaking people of the Eastern Part of Nigeria, West of Africa, where the word is gotten from, Madukaku is used to express the value placed on humans above other existing things. For this sect of African people; importance, worth, value, essence and high quality are attached or attributed to a human person over and above other things'(225).

The position expressed above is that human is more valued and supreme above every being that exist, Thus, for 'Madukakism the human is supreme' (226). However, such thinking is related to Protagoras postulation which says "Man is the measure of all things" which was admitted by Madukaku philosophy (266).

\subsection{Man is the Measure of All Things}

Man's pursuit to interpret humanity in the best possible way continues to reveal great thinkers who undertake this task. One of them is the famous the sophist and rhetorician Greek philosopher Protagoras, born in Abdera, in Thrace, who is known to have formulated the theory "Homo omnium rerum mesura est" ("Man is the measure of all things"), which tries to explain human existential situation (Wogu, 67). The accurate meaning of this dictum is a matter of deliberation when critical reflected upon: does it refer to man as an individual being, which would be absolute relativism, or to man as a being in general? Also, does "all things" mean the essence of intangible things or only those assessed by men? These are few of many questions surrounding this theory. Plato's Theaetetus claimed that Protagoras was given the honor of having propounded the homomensura theory from where the dictum was formed (Burrell, 30). This dictum which is "man is the measure of all things" is commonly accepted to have come to be as a result of the recognition of wide range of moral principles which in turn led to a universal maxim. By this dictum, Protagoras must have maintained that "all that men can possibly know are things as they appear to him" (Burrell, 30). However, 
this view is somehow related to Kant philosophy which is also of the opinion that human knowledge is restricted by the senses. In other words it holds that these senses alone can be appealed to in a final contest or debate. Katsoff corroborates this view when he said that:

It is not man's willfulness or arbitrariness that makes him the ultimate judge of 'things that are, that they are, and of things that are not, that they are not.' How else can you judge that things are except by human experience and knowledge? (Kattsoff, 454).

The truth concerning the above position is additional brought to light when Laszlo Versenyi affirmed that "The brevity of the fragment and the absence of direct elaboration by Protagoras about the meaning of the postulate gave rise to endless controversy about its meaning" (Versenyi, 178). To clinch such postulation is to hold that only what can be appended by the senses can only be regarded to as knowledge. This has serious implication for the subject of metaphysics and metaphysical objects. How can we know that God, mind and other abstract entities exist, since it cannot reduce by sense experience? Protagorian position about the gods and their existence; to a larger extent, did promote his 'man is measure of all things' dictum, and as well a major promoter of his agnosticism. He was known to have said: "Concerning the gods, I have no means of knowing whether they exist or not or of what sort they may be, because of the obscurity of the subject, and the brevity of human life" (TIEP, 2008). However, his position about god and the limitations of man punch his claims about his position of man in the 'man measure' maxim. This also gives us reasons to connect the entire dictum by Protagoras alongside the famous theorem in philosophy which says that: "Knowledge is Perception". This sort of thinking cannot be said to hold water in African traditional thought that are deeply religious and belief in phenomena's as witchcraft and reincarnation. To bracket them away just because it cannot be subjected to scientific investigation and mans senses is very brutal and simple amount to argumentum ad ignorantiam (fallacy of ignorance). Even from the ancient period there has been criticism by many who were dissatisfied with the principle. Taking Protagoras firmly by his words in the dictum, also in the light of this theorem 'knowledge is perception,' Socrates shows how false this maxim could be by merely appealing to facts of experience.

Accordingly, "If we have not learned a foreign language for instance, do we know it by merely hearing it spoken or seeing the script"? (Burrell, 196) Socrates asked. If that be the case, we must deny that we hear the words or see the writing, which we do not understand. If we have learnt it, then we know its meaning, that is, what we cannot see or hear. Invariably, we can conclude that knowledge and perception are thus not identical in learning a language. In a similar instance, we may ask: Is our knowledge of something the same whenever we see it a mile or yard away, does it matter whether we see it clearly or dimly, and so on. Evidently, illustrations above seem to knock out the theory and prove that the theorem is consistently declared erroneous. It should also be noted that Plato had warned us of the fallibility of our existential world with our sense perception included.

\section{Discussion}

Western philosophy conceives the transcendental notion of "being" by separating it from its attribute (force) but this cannot be said in African philosophy (Sakupapa, 423). Force in African thought is an indispensable element in being, and the concept force is inseparable from the definition of being. Devoid of the element force, being cannot be conceived. Since 'being' is force, all beings appear to the African as forces. This is the thrust of Placide 
Tempels Bantu Philosophy. According to Tempel's, It is not good enough to say that a person is a social being, because he feels and knows himself to be a vital force, at this very time to be in intimate and personal relationship with other forces acting above him and below him in the hierarchy of forces (Sakupapa, 432). He knows himself to be vital, even influencing some forces and likes influenced by others. The point being stressed by Tempels is that without a relationship with other members of the environing community, the Bantu human person cannot be. In summing up Tempels' position concerning the understanding of a person in an African traditional thought, one can say that Tempels considers Bantu man as a vital force who can realize complete life through interaction with other living forces, the supernatural world and nature (force).

Africans believes that there are hierarchy of beings in which God, lesser deities, ancestors, human and other lesser animals' etc follows (Mbiti, 135). Man in this ontology must act in respect towards every member in this ontology. Disrespecting anyone of them is disrespecting all, which has great consequence. The spirit of communalism, mutual respect cannot be taken away from African traditional system. The responsibility of man in the environment is caring, tending for God, lesser deities, ancestors. This is how African views land and other physical and non physical entities. For instance, Land is believed to be sacred because it carries the remains of the ancestors, principally in the form of graves. In the land is also buried the umbilical cord of natives and also believe to be the habitat of the dead. An individual who is not considered an indigene of a community is not allocated land, but if only if, he/she is accepted socially and politically in the community. Here, the continuous right to the land depended on his or her loyalty and obedience to the leadership of the community concerned. The land as an asset is not to be abused; this is the major reason while it is only given to persons who belong to the community, and also understands the significance and scared nature of the resource. Distribution and justice relating to land can be said to be egalitarian; this is because there is always a consequence as God and the ancestors would deal ruthlessly with anyone who tried to cheat the other who tries to abuse or cheat any other person.

On the death of whosoever uses the land, it will be given back to the community. At times, his or her immediate family members can be allowed to continue to use the land, but again, they must continue to exhibit loyalty and respect to the land and community (Amanor, 56). It is vital to stress that although a person may acquire land and have right to its usage even for life, but the truth is that the individual did not own the land as such but benefit from its usufruct. This is because as noted earlier on, the real owners of the land in any community in Africa are the ancestors on whose stead the chief stands. That is, the chief has the supervision of all land in his jurisdiction. Furthermore, this is communal principle is also extended to other phenomena's in the environment which shares biotic community with man. Africans believes strongly that there is a force behind everything created, this is why most times he often pour libration before undertaking some specific exploitation of nature. In many rituals libations are poured on land, as it is a medium that connects man to the metaphysical (Stewart, 3). Libation is a ritual of heritage, a drink offering to honor and please the Creator, the lesser divinities, our sacred ancestors, humans present and not present, as well as the environment (Stewart, 3). This is often done to acknowledge the force interwoven between them, knowing their importance and value and furthermore affording them appropriates respect. If the position of Madukaku (man being supreme, and man being the measure of all 
thing) in African thought is true then there won't be any need of going through this process as man may carry out his dealings, negating other force in the environment.

Furthermore, there are taboos and totems in African cultures which is to regulate man relations with other beings within the environment. The communitarian nature of an African society can be understood in the context of the moral relationship that is struck between the individual and the environment through the observance of taboos. Chemhuru and Masaka defined taboos as avoidance rules that forbid members of the human community from performing certain actions, such as eating some kinds of food, walking on or visiting some sites that are regarded as sacred, cruelty to non-human animals, using nature's resources in an unsustainable manner (Chemhuru and Masaka, 123). This laws are enacted by the ancestors to checkmate mans excess and reminds Man that he is in a biotic community with other beings how shares same moral status. The right to confer moral status lies with the highest being in the hierarchy which is God. This defeats the idea the 'human is supreme' (226), which Madukakism postulates. Enyimba Maduka had did quote Udobata Onunwa in his -The Individual and Community in African Traditional Religion and Society" saying that;

While not the lord of the universe in Igbo cosmology, man believes himself to be at the centre of the universe, where the pressures and influences of all other things converge and operate. Man is then important (258).

There is no denial that man holds an important place in African ontology, but this does not imply that man lords over the environment. To this Mbiti in African religion and the world order claim that humans are not masters over nature to exploit it without feeling or treat it without respect (368). Instead people are one with nature, responsible toward nature, able to communicate with nature, and the chief priests of nature. This position is also echoed by Ekwealo who argues that Africans do not believe that human being is a special image of God who was charged with the lord over nature. Rather, Africans believe in the unity of forces, and human special position is rather more of a caretaker of the universe, a task which goes with appropriate responsibility and consequences (197).

\section{Conclusion}

Rejecting the communitarian principles of African traditional thought is rejecting the entire philosophy and culture of the Africans. Africans believe man has a special place among nature and the environment, but this special place is like the position of a caretaker. A caretaker is someone who in same house as tenants, pays rent, relates with all co-tenets mutually and also fulfills other obligation. The caretaker is an important personality as long as the house is concern but going to the extent of branding him supreme is an overstatement. Likewise, man cannot be said to be lord over the universe and the measure of all things in African communal culture. This is because he lives with other being in the environment and further constitute to the missing link, assorted part or substances of which reality is constituted (Asouzu, 321). The thinking of 'Man being supreme' has lead to several problems which have stained and affected our environment negatively. Such similar thinking, as influenced some persons believing to be superior to others, which has lead to colonialism. This thinking has also led to class struggle and alienation of persons in a world where there are enough resources for everyone but yet larger of the world's population remains in poverty. This kind of thinking is alien to African philosophical system. Communitarian principles is very important that it is found in every aspect of African cultural experiences from child rearing to death; every aspect of an African interaction. To play down African 
communalism as Madukaku philosophy did is to reject African Philosophy and culture as a whole. Hence such philosophy and thinking cannot be said to be African.

\section{References}

Amanor, K. (2001). Land, labor and the family in Southern Ghana: A critique of land policy under neo-liberalization. Goteborg, Sweden: Elanders Gigitaltryck AB.

Asouzu I. Innocent, .IbuanyidandaComplementary Reflection and some basic Philosophical Problems in Africa Today; Sense Experience, "IheMkpuchiAya" and The Super Maxim, Litverlag Ambh\& Co. KG Wien, Zurich, 2013

Atwell, J. E. (1969). Existence precedes essence. Man and World, 2(4), 580-591. http://doi.org/10.1007/BF01249074

Burrell, P. S. (1932). Man the Measure of All Things: Socrates Versus Protagoras (I). Philosophy, 7(25), 27-41. http://doi.org/10.1017/S0031819100053638

Çelebi, V. (2014). Existentialist Thought According to Jean Paul Sartre. Beytulhikme An International Journal of Philosophy, 4(2). http://doi.org/10.1186/1824-7288-36-71

Chemhuru, M and Masaka, D. 2010. Taboos as source of Shona people's environmental ethics. Journal of Sustainable Development in Africa. Vol 12 No. 7.

Ekwealo, C. J. 2004. "African environmental values expressed through proverbs", In Appleton. J. 2014. Values in sustainable development. Abingdon, New York: Routledge.

Kattsoff, L. O. (1953), Man is the Measure of all Things, Philosophy and Phenomenological Research, Vol. 13, No. 4 (Jun., 1953), pp. 452-466. Published by: International Phenomenological Society. http://www.jstor.org/stable/2103811 .Accessed: 08/11/2012 10:29.

Maduka, Enyimba. (2018), Madukaku as the basis of Being Human in (Igbo) African worldview. Proceedings of the Society for Research and Academic, $8^{\text {th }}$ International Conference. Date; $5^{\text {th }}$ to 8 Feburary 2018. 224-229

Mbiti, J. 1975. Introduction to African religion. London: Heinemann.

TIEP, (2008), The Internet Encyclopedia of Philosophy - Protagoras (c. 490 - c. 420 BCE), Accessed: October 6, 2018.

Versenyi. L. (1962). Protagoras' Man-Measure Fragment. The American Journal of Philology, Vol. 83, No. 2 (Apr., 1962), pp. 178-184. The Johns Hopkins University Press.: http://www.jstor.org/stable/292215. Accessed: 08/11/2012 09:21.

Wogu, I. A. (2010), A Preface to Philosophy, Logic and Human Existence, Pumark Nigeria Limited. P. 67. 